\title{
OPTIMASI WEBSITE MENGGUNAKAN METODE SEARCH ENGINE OPTIMIZATION (SEO) ON PAGE DAN OFF PAGE DALAM MENINGKATKAN TRAFIK KUNJUNGAN (STUDI KASUS: HUSTLE MEDIA GRUP)
}

\author{
Fadila Darojatu Sidqi ${ }^{1)}$, Hendra Marcos ${ }^{2)}$ \\ 1) Sistem Informasi Universitas Amikom Purwokerto \\ 2) Informatika Universitas Amikom Purwokerto \\ email : fadilads10@gmail.com ${ }^{1)}$, hendra.marcos@gmail.com ${ }^{2)}$
}

\begin{abstract}
Abstraksi
Perkembangan penggunaan internet di Indonesia mengalami kenaikan yang pesat dan Google merupakan mesin pencari yang paling banyak digunakan. Hal ini mendorong para pelaku industri untuk mendapatkan pasar yang lebih besar melalui sebuah website dan menerapkan metode SEO. Hustle Media Grup merupakan sebuah perusahaan kreatif industri produk dan jasa, photography, cinematography, craft, design, dan printing yang dikemas dalam produksi album kenangan sekolah yang didirikan pada tahun 2014. Website Hustle Media belumlah terfokus secara penuh pada penerapan SEO pada website mereka dan barulah menerapkan SEO pada homepage website, meta description dan pengulangan kata sehingga hal tersebut menyebabkan sedikit adanya kenaikan traffic.
\end{abstract}

Kata Kunci :

Implementasi SEO, Trafik Kunnjungan, Website

\begin{abstract}
The development of internet use in Indonesia has increased rapidly and Google is the most widely used search engine. This encourages industry players to get a bigger market through a website and apply SEO methods. Hustle Media Group is a creative company in the product and service industry, photography, cinematography, craft, design, and printing packaged in the production of school memorabilia which was founded in 2014. The Hustle Media website has not fully focused on implementing SEO on their website and then implementing SEO on the website homepage, meta description and word repetition so that it causes a slight increase in traffic.
\end{abstract}

\section{Keywords :}

SEO Implementation, Traffic Visits, websites

\section{Pendahuluan}

Perkembangan penggunaan internet di Indonesia mengalami kenaikan yang pesat dan hal tersebut di perkuat dengan hasil survey yang dilakukan oleh Asosiasi Penyelenggara Jasa Internet Indonesia (APJII) pada tahun 2018 dan Google merupakan mesin pencari yang paling banyak digunakan karena dianggap mampu memberikan informasi apapun hanya dengan memasukkan sebuah kata kunci pada kotak penelusuran [1]. Hal ini mendorong para pelaku industri untuk mendapatkan pasar yang lebih besar dikarenakan adanya peluang tersendiri untuk melakukan perdagangan ataupun mempromosikan barang ataupun jasa melalui sebuah website dan salah satu langkah yang dilakukan adalah dengan menerapkan metode Search Engine Optimization (SEO). Salah satu perusahaan yang mulai menyadari terhadap potensi SEO adalah website Hustle Media.

Hustle Media Grup merupakan sebuah perusahaan kreatif industri produk dan jasa, photography, cinematography, craft, design, dan printing yang dikemas dalam produksi album kenangan sekolah (yearbook industry) yang didirikan pada tahun 2014. Awal mulanya pemilik perusahaan mendirikan perusahaan Hustle Media dengan menggunakan akun sosial media personal yang mana sosial medianya adalah menggunakan instagram yang bernama Gaza. Karena dirasa pemilik sudah memiliki nama dan pasar yang cukup luas sebelumnya, maka pemilik memutuskan mengubah sosial media pribadinya menjadi sosial media perusahaannya yang diberi nama@hustlemediagrup.

Seiring berjalannya waktu, pemilik perusahaan ini merasa ingin menjangkau 
pasar yang jauh lebih luas dan cara yang dilakukan adalah dengan membangun sebuah website yang beralamatkan pada www.hustlemdia.id. Website tersebut merupakan sebuah situs website profile dan promosi produk. Adapun produk yang di promosikan diantaranya seperti yearbook, school event documentation, wedding cinematography dan media periklanan.

Berdasarkan hasil wawancara yang telah dilakukan dengan tim IT perusahaan tersebut menyatakan bahwa penggunaan website Hustle Media Grup belumlah optimal dikarenakan website ini barulah diperuntukkan untuk operasional ke klien belum untuk ke arah komersial. Selain itu, website ini belum genap berumur satu tahun yakni sekitar 7 bulan terhitung sejak bulan Maret 2020. Disisi lain, website yang didirikan oleh Hustle Media belum terfokus secara penuh pada penerapan Search Engine Optimization (SEO). Hanya terfokus pada homepage website, meta description dan pengulangan kata saja. Dari penjabaran tersebut, terdapat dua macam permasalahan yang melandasi peneliti untuk mengabil penelian dengan metode ini yaitu dikarenakan belum terfokusnya secara penuh pada penerapan SEO (Search Engine Optimization) yang mana hal tersebut menyebabkan website tidak mengalami kenaikan trafik kunjungan dan peningkatan rangking terhadap website tersebut berdasarkan kata kunci tertentu.

Dengan diterapkannya metode SEO (Search Engine Optimization) terhadap website milih Hustle Media ini diharapkan dapat lebih membantu Hustle Media dalam menjangkau pasar yang jauh lebih luas lagi. Dikarernakan, dengan kondisi pasar yang semakin luas jangkauanpun tidak lagi menjadi personal to company melainkan diharap menjadi company to company

\section{Tinjauan Pustaka}

Dalam Optimasi Website Menggunakan Metode SEO (Search Engine Optimization) On Page dan Off Page Dalam Meningkatkan Trafik Kunjungan peneliti menggunakan penelitian sebelumnya yang merujuk pada konsep penelitian yang akan dilakukan.

Penelitian yang dilakukan oleh Fahir (2020) yaitu Penerapan SEO (Search Engine Optimization) Dengan Teknik On Page Pada Website AMPU Studio. Tujuan penelitian tersebut adalah untuk menerapkan teknik SEO on page pada pada website AMPU Studio yang mana dapat digunakan untuk meningkatkan Search Engine Result Page
(SERP) pada website AMPU Studio dengan kata kunci "Jasa Pembuatan Animasi" dan penerapan kata kunci di muat pada meta title, meta description dan artikel. Setelah diterapkannya teknik SEO on page website berangsur-angsur terindex hingga berada di peringkat ke-7 dan ke-43 yakni pada halaman ke-1 dan halaman ke-4 pada mesin pencari Google dengan wakru implementasi kurang lebih 1 bulan [2].

Penelitian yang dilakukan oleh Azim dkk (2019) yaitu Penerapan Teknik SEO (Search Engine Optimization) Dengan Metode On Page Dan Off Page Pada Website Cargoriau.com. Tujuan penelitian tersebut adalah untuk menerapkan teknik SEO on page dan off page yang berguna dapat menempatkan posisi website Cargoriau.com di halaman satu mesin pencari sehingga mendatangkan banyak trafik atau kunjungan yang berpotensi untuk menunjang promosi Jasa Cargo Zataka Express Group. Pada penelitian ini, optimasi dilakukan selama 3 bulan dan diantaranya keyword yang diuji coba adalah "Cargo Pekanbaru Tembilahan" dan "Ekspedisi Pekanbaru Dumai". Setalah diterapkannya metode SEO, website CargoRiau tampil pada halaman 1 dengan beberapa keyword yang di targetkan [3].

Penelitian yang dilakukan oleh Sinaga \& Hadinata, (2019) yaitu Implementasi Teknik Search Engine Optimization Dalam Meningkatkan Trafik Website Bima Utomo Waterpark. Tujuan penelitian tersebut adalah membuat website bisnis atau usaha yang dapat meningkatkan popularitas bisnis secara online melalui pencarian di mesin pencari. Untuk meningkatkan popularitas website Bima Utomo Waterpark menggunakan teknik SEO tentunya dengan pemilihan kata kunci atau keyword yang tepat. Pada proses optimasi SEO pada website Bima Utomo Waterpark ada 3 keyword yang dijadikan target yaitu "Waterpark Medan", "Bima Utomo", dan "Bima Utomo Waterpark". Penempatan keyword dilakukan pada judul artikel, di dalam artikel, dan pada meta keyword dalam coding 25 program. Optimasi pada website Budi Utomo Waterpark dilakukan selama 1 bulan dengan menempati posisi ke-11 dengan keyword "Waterpark Medan", posisi ke-4 dengan keyword "Bima Utomo", dan posisi ke-5 dengan keyword "Bima Utomo Park" pada halaman pencari Google [4].

\section{Metode Penelitian}

a. Studi Literatur 
Pada penelitian ini studi literatur dilakukan dengan cara mengumpulkan informasi dan beberapa buku ataupun jurnal dan mempelajarinya agar dapat menemukan masalah yang sedang diteliti menegnai metode SEO (Search Engine Optimization).

b. Observasi

Pada penelitian ini observasi dilakukan dengan cara mengunjungi website perusahaan Hustle Media dan melihat apakah pada website tersebut sudah menerapkan metode Search Engine Optimization (SEO).

c. Wawancara

Penulis membuat panduan untuk wawancara dengan pertanyaan yang tentunya singkat dan juga jelas dan berfokus terhadap hal-hal yang dibutuhkan pada penelitian, seperti menanyakan apakah pada website Hustle Media sudah menerapkan metode Search Engine Optimization (SEO).

d. Dokumentasi

Pada langkah ini, dokumentasi berbentuk sebuah informasi yang dibutuhkan oleh peneliti untuk membuat website Hustle Media mengalami peningkatan pada trafik kunjungan website-nya. Data yang dibutuhkan berupa dokumentasi dari sosial media Instagram guna mendukung dalam peningkatan trafik kunjungan.

\section{Hasil dan Pembahasan}

a. Trafik Kunjungan

Setelah dilakukannya serangkaian metode SEO terhadap website Hustle Media maka hal yang selanjutnya dilakukan adalah dengan melakukan testing apakah metode SEO yang telah diterapkan berpengaruh terhadap trafik kunjungan website Hustle Media atau tidak. Tools yang digunakan untuk mengetahui ada tidaknya kenaikan trafik adalah dengan mengggunakan tools Google Analitycs. Dari pengujian yang sudah dilakukan didapatkan sebuah data dimana data tersebut menunjukan sebuah perubahan pada kenaikan kunjungan yang begitu signifikan yang mana pada bulan Juni sebelum diterapkannya metode SEO trafik kunjungan tertera sebanyak 65 user, pada bulan November dan Desember setetlah diterapkannya metode SEO trafik kunjungannya mencapai 344 dan 213 user. Pada bulan November ke Desember trafik kunjungan mengalami penurunan, namun untuk pencarian organiknya mengalami sebuah kenaikan yang mana sebelumnya hanyalah 9 pencarian, pada bulan Desember pencarian organiknya mencapai 16 pencarian.
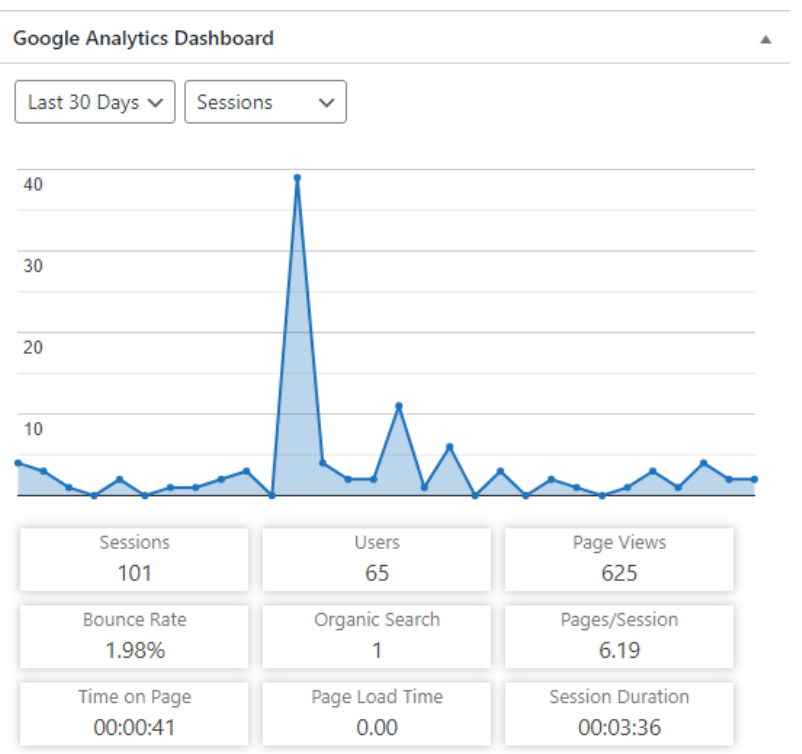

Gambar 1. Trafik Kunjungan Bulan Juni Sebelum Diterapkannya SEO
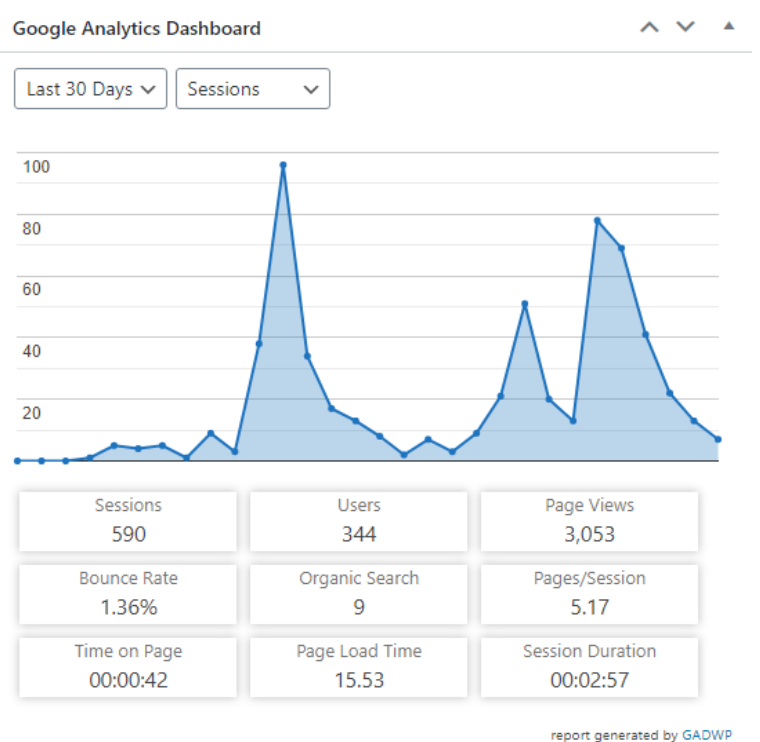

Gambar 2. Trafik Kunjungan Bulan November Setelah Diterapkannya SEO

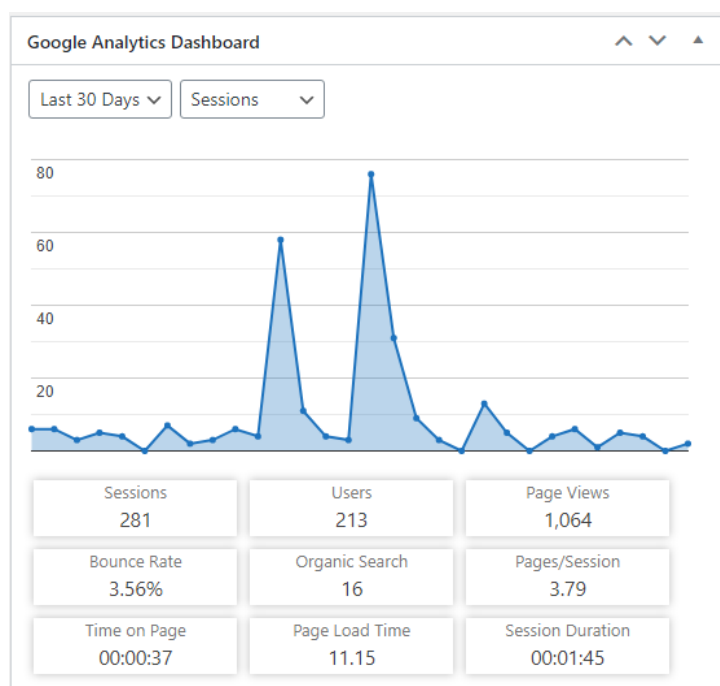


Gambar 3. Trafik Kunjungan Bulan Desember Setelah Diterapkannya SEO

b. Backlink

Penerapan backlink terhadap website Hustle Media dilakukan dengan cara menyematkan link pada bio Instagram yang memiliki username@ @hustlemediagrup dan menyematkan hastag yang memuat kata kunci pada setiap postingannya. Untuk pengujian backlink digunakan sebuah tools bernama Seoreviewtools dengan memanfaatkan menu-nya yaitu Checker Backlink. Dari pengecekan yang sudah dilakukan didapatkan hasil bahwa jumlah backlink pada website Hustle Media sebanyak 14 external backlink.

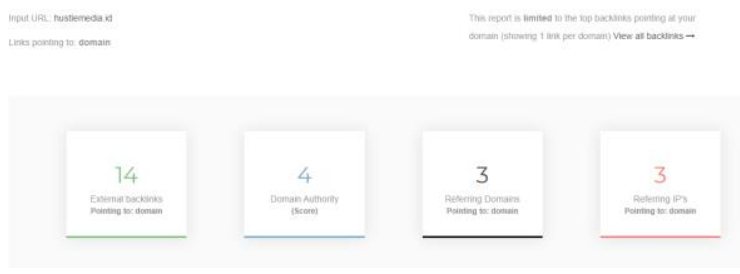

Gambar 4. Hasil Backlink

c. Kata Kunci

Pengecekan sebuah kata kunci termasuk hal yang penting dan alat yang digunakan untuk cek kata kunci yang sudah ditanam adalah dengan menggunakan tools Whatmyserp. Pada tangal 5 Januari 2021 dilakukan sebuah testing terhadap kata kunci yang sudah di tanam di dalam website Hustle Media yang menyatakan bahwa untuk kata kunci "jasa pembuatan yearbook sma" berada pada peringkat ke-3 yang artiya website tersebut berada pada halaman $\mathrm{ke}^{-1}$ pada mesin pencari Google. Sedangkan untuk kata kunci "yearbook" dan "yearbook sma" belumlah terdeteksi oleh mesin pencari Google.

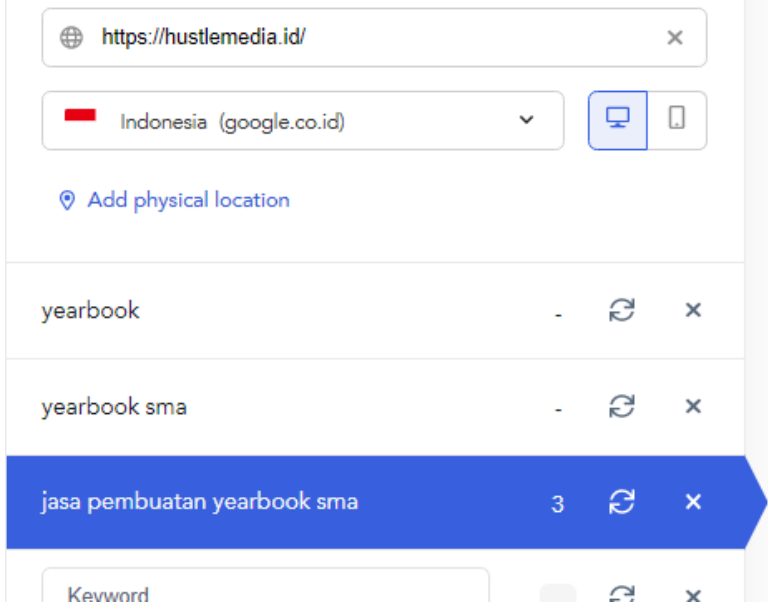

Gambar 5. Hasil Test Peringkat Website

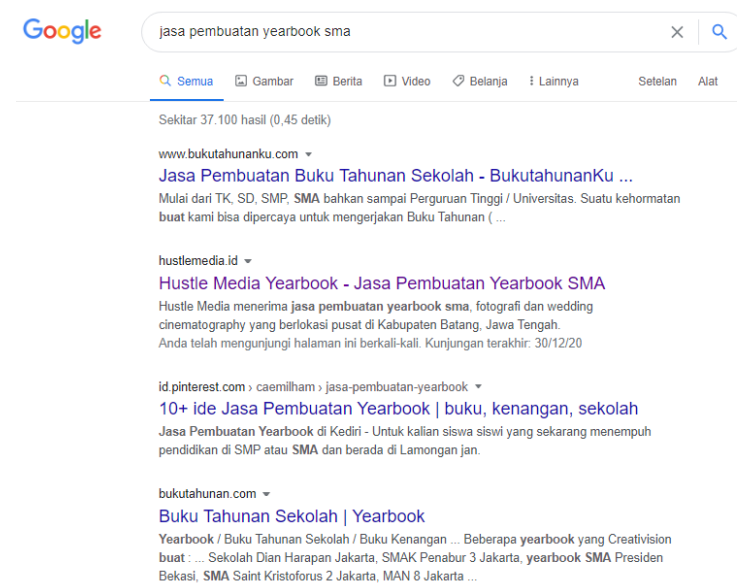

Gambar 6. hasil Pencarian pada Mesin Pencari Google

\section{Kesimpulan dan Saran}

Berdasarkan hasil dari diterapkannya metode SEO terhadap website Hustle Media guna menaikan trafik kunjungan dikatakan berhasil dikarenakan trafik kunjungan mengalami kenaikan yang sangat signifikan. Pada bulan Juni trafik kunjungan hanya tertera 65 user, pada bulan November trafik kunjungan naik menjadi sebanyak 344 user, sedangkan di bulan Desember trafik kunjungannya mengalami penurunan dan tertera sebanyak 213 user. Namun untuk pencarian organiknya mengalami kenaikan dibandingkan bulan Juni dan November yang tadinya hanya 1 pencarian organik pada bulan Juni, 9 pada bulan November, dan 16 pada bulan Desember. Dan terjadi persentase kenaikan trafik sebanyak 5,29\% dari bulan Juni hingga bulan November 2020. Sedangkan untuk penanaman kata kunci "jasa pembuatan yearbook sma" dikatakan sukses karena dapat ter-index oleh Google dan menempati peringkat $\mathrm{ke}^{-3}$ atau berada pada halaman ke-1 mesin pencari Google.

\section{Daftar Pustaka}

[1] APJII, Penetrasi \& Profil Perilaku Pengguna Internet Indonesia Tahun 2018. Apjii, 51. Diambil dari www.apjii.or.id diakses pada 15 April 2020.

[2] O. Fahir, "Penerapan Seo (Search Engine Optimization) Dengan Teknik On Page Pada Website Ampu Studio (Studi Kasus: Pt. Ampu Kreatif Studio". Skripsi. Purwokerto: Universitas Amikom Purwokerto.2020

[3] F. Azim, "Penerapan Teknik Seo (Search Engine Optimisation) Dengan Metode Onpage Dan Offpage Pada Website 
Vol. 3, No. 1 (2021)

Cargoriau.Com". Riau Journal of Computer Science. 5(1), 32-37.2019

[4] Sinaga, T. H., dan Hadinata, E., "Implementasi Teknik Search Engine Optimization Dalam Meningkatkan Trafik Website Bima Utomo Waterpark". QUERY: Jurnal Sistem Informasi. 3(2), 19.2019 